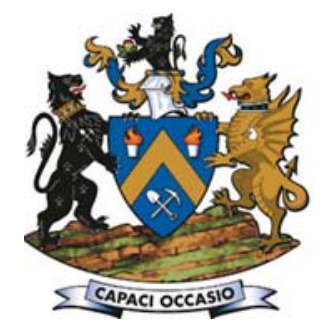

\title{
Modes of arsenic occurance in coal slime and its removal: a case study at the Tanggongta Plant in Inner Mongolia, China
}

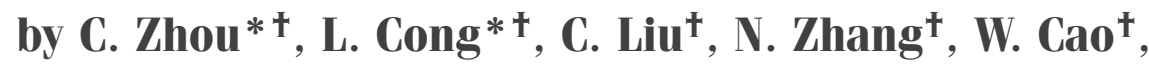 \\ J. Pan ${ }^{\dagger}, X$. Fan* ${ }^{*}$, and H. Liü**
}

\section{Synopsis}

The modes of occurrence of arsenic and the effects of low-intensity leaching-flotation on arsenic removal from coal slime from the Tanggongta Plant, Inner Mongolia, China were investigated. The coal slime was examined using hydride generation inductively coupled plasma optical emission spectrometry and X-ray diffraction to obtain the content of elements and the major minerals. The modes of occurrence of arsenic in minerals were determined using selective leaching, float-and-sink analysis, and polarized light microscopy. The results indicate that pyrite is the dominant carrier of arsenic in the coal slime, which predominantly exists in association with clay. Significant proportion of the arsenic is removed by a low-intensity leaching-flotation process, consistent with the data from selective leaching and flotation of gangue. The results show that low intensity leaching-alkali washing-flotation is more efficient than direct flotation and low-intensity leaching-flotation.

Keywords

arsenic removal, coal slime, low-intensity leaching, flotation.

\section{Introduction}

Understanding the occurrence of arsenic in coal and its removal is significant in optimizing coal utilization, because arsenic in the environment is viewed as a potentially toxic trace element (Finkelman, Belkin, and Zhang, 1999; Hall, 2002; Smith et al., 1992; Smedley et al., 2003; Zheng et al., 1999). Many studies on the modes of occurrence and concentration trends of arsenic in different coal and washing products have been performed (Diehl, Goldhaber, and Hatch, 2004; Kolker et al., 2000; Quick and Irons, 2002; Wang et al., 2006; Fan et al., 2016). Trace elements are usually preferentially associated with certain minerals and the form that these minerals take will influence the efficiency of removal during cleaning (Quick and Irons, 2002). Arsenic is mainly associated with minerals such as pyrite, carbonate, and silicate (Demir et al., 1998; Diehl, Goldhaber, and Hatch, 2004; Zhou et al., 2014). The existence of organically bound arsenic was also confirmed using X-ray absorption (Kolker et al., 2000). However, inorganic arsenic is the principal source of pollution because of its leachability and high concentration compared with organic arsenic (Fujino et al., 2004; Gao, Lu, and Wang, 2010; Jiang et al., 2008; Kolker et al., 2000).

Coal combustion is a major process for the release of trace elements, such as arsenic, mercury, and fluorine, to the environment (Dai et al., 2014; Finkelman et al., 2002; Kolker et al., 1999). Arsenic can be removed before, during and after coal combustion (Gao, Lu, and Wang, 2010). However, coal washing is a more efficienct and lower cost method of arsenic removal (Demir et al., 1998; Feng, 2009). Arsenic and mercury can be removed to a high degree in the process of coal cleaning (Wang et al., 2006). Finkelman studied the effects of trace elements on coal washability (Finkelman, 1994). Physical and physicochemcial coal washing techniques such as gravity separation and flotation can remove $50-80 \%$ of the harmful trace element content from the coal product (Luttrell, Kohmuench,

* School of Chemical Engineering and Technology, China University of Mining and Technology, Xuzhou, Jiangsu, China.

$+\quad$ Key Laboratory of Coal Processing and Efficient Utilization (Ministry of Education), China University of Mining \& Technology, Xuzhou, Jiangsu, China.

¥ Jiangxi Key Laboratory for Mass Spectrometry and Instrumentation, East China University of Technology, Jiangxi, China.

* * Xuzhou Environmental Monitoring Center Station, Xuzhou, Jiangsu, China

(C) The Southern African Institute of Mining and Metallurgy, 2017. ISSN 2225-6253. Paper received Jul. 2015; revised paper received Mar. 2016. 


\section{Modes of arsenic occurrence in coal slime and its removal}

and Yoon, 2000; Zheng, Liu, and Chou, 2008). Furthermore, demineralization or desulfurization of coal by chemical coal cleaning techniques has been reported by many investigators (Meshram et al., 2015; Waugh and Bowling, 1984; Pietrzak and Wachowska, 2006; Xia, Xie, and Peng, 2015). Waugh and Bowling, 1984 reported 90\% reduction of the mineral matter content of an Australian coal after a caustic wash. Pietrzak and Wachowska (2006) considered that treatment with $\mathrm{HNO}_{3}$ is effective for the removal of pyrite in coal desulphurization. As the harmful trace elements generally occur in minerals (e.g. pyrite and carbonate), chemical techniques are essential for their removal.

Arsenic can enter the human body through various channels such as the respiratory tract, digestive tract, and by skin contact (Finkelman, Belkin, and Zheng, 1999; Smedley et al., 2003; Zheng et al., 1999). Chronic arsenic poisoning may induce cancer, hypertension, diabetes mellitus, and cardiovascular and cerebrovascular diseases, etc. (Smith et al., 1992; Hall, 2002). Wang et al. (2006) reported that trace elements such as arsenic, mercury, sulphur, etc., tend to become enriched in coal slime. The annual production of coal slime in China is more than $70 \mathrm{Mt}$ tons. In order to be able to estimate mass emissions of arsenic and also to develop costeffective, efficient removal technologies in the future, it is necessary to research the occurrence, deportment, and removal of trace elements like arsenic in the coal slime washing process. Most of the arsenic removal techniques in coal preparation have utilized gravity and flotation methods, and the effect of a low-intensity leaching-flotation removal method on a low-rank bitumite has not yet been explored. Apart from this, most of the modes of occurrence of arsenic on low-rank bitumite have also not been critically assessed. In this study, we present semi-quantitative and quantitative results on the mineral content, speciation, and modes of occurrence of arsenic in coal slime from Inner Mongolia. The effectiveness of low-intensity leaching-flotation for the removal of arsenic with various modes of occurrence is also discussed.

\section{Experimental}

\section{Materials and methods}

A coal slime sample was collected from Tanggongta coal preparation plant in Inner Mongolia, China. According to China national standards for coal classification (GB5751-86), the sample is classified as long-flame coal (CY42). The sample was dried at $70^{\circ} \mathrm{C}$ for 3 hours after screening.

The experimental procedure is shown in Figure 1. Coal slime was separated by heavy liquids with densities of 1.4 , $1.5,1.6,1.7$, and $1.8 \mathrm{~g} / \mathrm{cm}^{3}$, using mixtures of benzene, carbon tetrachloride, and bromoform at appropriate ratios, following Chinese standards (GB/T 478-2008).

After float-and-sink and flotation experiments coal slime solids were digested with $\mathrm{HNO}_{3}(5 \mathrm{~mL}, 68 \%(\mathrm{w} / \mathrm{w}))$ and $\mathrm{HF}$ (5mL, $48 \%(w / w))$ by a microwave digestion system (MDS) into liquid samples, which were analysed by hydride generation inductively coupled plasma optical emission spectrometry (HG-ICP-OES) for As, Al, and Fe. Forward power was $1200 \mathrm{~W}$. Nebulizer, auxiliary, and coolant argon speeds were $0.8 \mathrm{~L} / \mathrm{min}, 0.75 \mathrm{~L} / \mathrm{min}$, and $13.50 \mathrm{~L} / \mathrm{min}$, respectively. The internal Tm standard was used to determine the detection limit $(0.50 \mathrm{pg} / \mathrm{mL})$ and error range (less than $2.0 \%)$.

Mineralogical and petrographic characteristics of the coal slime and gangue were determined using X-ray diffraction (Philips PW 1830 diffractomoter system using $\mathrm{Cu} \mathrm{K}$ radiation) and optical microscopy (ZEISS Imager M1m), respectively.

The flotation tests were conducted with the addition of collector (diesel $20.0 \mathrm{~kg} / \mathrm{t}$ ) and frother (sec-octyl alcohols 5.0 $\mathrm{kg} / \mathrm{t}$ ). After being washed with deionized water and dried,

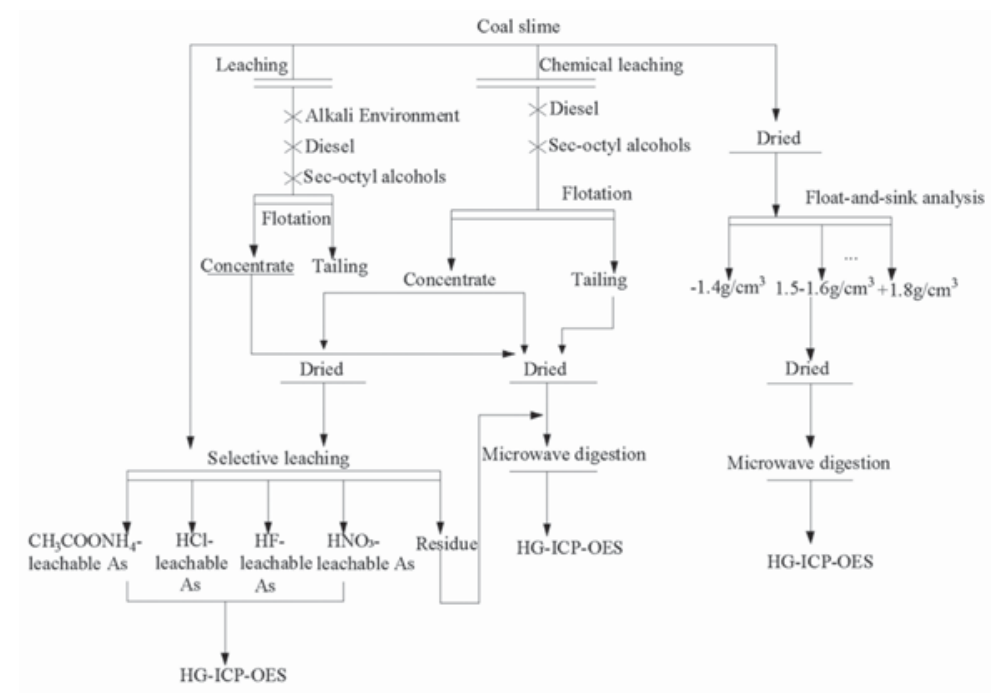

Figure 1-Sample preparation process for chemical leaching-flotation, float-and-sink, and selective leaching analysis 


\section{Modes of arsenic occurrence in coal slime and its removal}

flotation tailings and concentrate were used as fine mud and coal particles, respectively. Fine mud and coal particles were mixed with deionized water to produce slurry with a liquidsolid ratio of $1: 10 . \mathrm{HNO}_{3}$ and $\mathrm{NaOH}$ were added to the slurries to adjust the $\mathrm{pH}$ to values from 1.0 to 12.0. The samples, adjusted to different $\mathrm{pH}$ values, were agitated 30 minutes and transferred to a beaker. After standing for 24 hours, the zeta potential of the supernatant liquid was measured by ZetaPALS.

\section{Selective leaching}

Selective leaching was carried out on duplicate $5.0 \mathrm{~g}$ coal samples. Raw coal slime and clean coal were ground to pass a 200 mesh sieve, and sequentially extracted with $35 \mathrm{~mL}$ of $1 \mathrm{~N} \mathrm{CH}_{3} \mathrm{COONH}_{4}, 3 \mathrm{~N} \mathrm{HCl}, 48 \%$ (w/w) $\mathrm{HF}$, and $2 \mathrm{~N} \mathrm{HNO}_{3}$ at room temperature (Kolker et al., 2000). After each extraction, the leachable fraction was centrifuged and the clear solution was analysed by HG-ICP-OES. The sequence of leaching steps used was adopted so that arsenic associated with various components of the coal would be removed as shown in Table I.

\section{Low-intensity leaching-flotation}

Two consecutive steps of first low-intensity leaching and flotation were performed. In the first step, coal slime was leached by agitation and aeration. The low-intensity leaching process was investigated at stirring speeds of $150 \mathrm{~min}^{-1}$ at $303 \mathrm{~K}$ to dissolve some of the inorganic mineral content of coal. The leach slurry was prepared by mixing $100 \mathrm{~g}$ of coal slime with $1000 \mathrm{~mL}$ deionized water in $1500 \mathrm{~mL}$ bottles. $\mathrm{HNO}_{3}$ and $\mathrm{NaOH}$ were then added to adjust the $\mathrm{pH}$ of the slurry to $1.0,3.0,5.7,10.0$, and 12.0 in order to compare the leaching-flotation behaviour of arsenic following pretreatment in acid, neutral, and alkali environments. The leach residue was collected using centrifugal separation after 1 hour and washed three times with deionized water and then transferred to a flotation cell (XFD-1.0 L), where the pulp density was adjusted to $80 \mathrm{~g} / \mathrm{L}$. The $\mathrm{pH}$ of the flotation pulp

\begin{tabular}{|l|l|}
\hline \multicolumn{2}{|l}{$\begin{array}{l}\text { Table I } \\
\text { Selective leaching stages and the minerals }\end{array}$} \\
\hline Selective leaching stage & \multicolumn{1}{|c}{ Minerals likely to be decomposed } \\
\hline $1 \mathrm{CH}_{3} \mathrm{COONH}_{4}$ & $\begin{array}{l}\text { Exchangeable cations and a portion of the } \\
\text { carbonate-hosted cations }\end{array}$ \\
\hline $2 \mathrm{HCl}$ & $\begin{array}{l}\text { Carbonates and monosulphides (sphalerite, } \\
\text { galena, and chalcopyrite) }\end{array}$ \\
\hline $3 \mathrm{HF}$ & $\begin{array}{l}\text { Silicates, including those hosted by the } \\
\text { clay minerals (illite and kaolinite) }\end{array}$ \\
\hline $4 \mathrm{HNO}_{3}$ & \begin{tabular}{l} 
Disulphides (pyrite and marcasite) \\
\hline
\end{tabular}
\end{tabular}

Note: Elements remaining in the solid residue may be present in the organic matrix, or occur in insoluble phases such as zircon or one of the titanium dioxide polymorphs. was between 5.6 and 5.7. The flotation tests were started with the addition of collector (diesel $20.0 \mathrm{~kg} / \mathrm{t}$ ) and frother (sec-octyl alcohols $5.0 \mathrm{~kg} / \mathrm{t}$ ). After flotation, the concentrate was dried and analysed.

\section{Low-intensity leaching- alkali environment - flotation}

Low-intensity leaching was carried out in the optimal $\mathrm{pH}$ conditions $\left(\mathrm{pH}=1, \mathrm{HNO}_{3}\right)$ and the other conditions of leaching remained unchanged. After low-intensity leaching and deionized water washing, the sediment from centrifugal separation was transferred to a flotation cell (XFD-1.0 L). A solution of $10 \%(\mathrm{v} / \mathrm{v}) \mathrm{NaOH}$ was added to the deionized water to adjust the initial $\mathrm{pH}$ to 10 , which was subsequently adjusted to $\mathrm{pH}$ of 8.0-9.0 and a pulp density of $80 \mathrm{~g} / \mathrm{L}$.

\section{Results and discussion}

\section{Mineral composition and occurrence}

Figure 2 shows the XRD pattern of coal slime. The mineral assemblage is dominated by quartz and clay minerals (e.g. kaolinite and chlorite) with trace amounts of pyrite, carbonate, and bohmite. The pyrite occurs mainly in association with quartz and with clay minerals, (Figue 3) rather than as free pyrite. The relative contents of quartz and

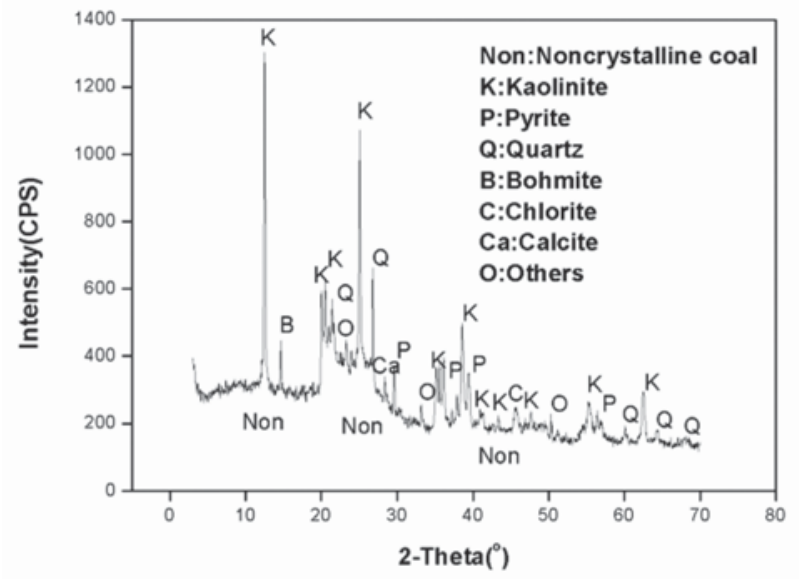

Figure 2-X-ray diffraction pattern of coal slime

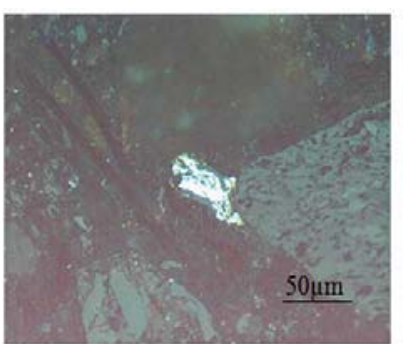

(a)

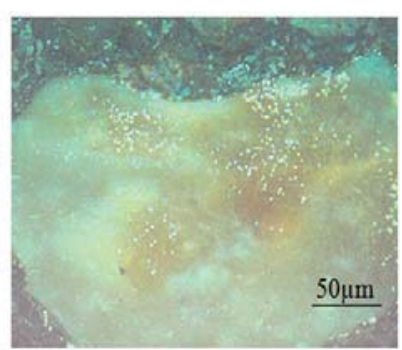

(b)
Figure 3-Occurrences of clay and pyrite in the coal slime: Disseminated pyrite and kaolinite (a); disseminated pyrite and quartz (b) 


\section{Modes of arsenic occurrence in coal slime and its removal}

clay are different. Table II shows the content of major minerals in coal slime obtained by petrographic analysis. The relative contents of clay and pyrite are $85 \%$ and $11 \%$ (by volume), respectively. Quartz accounts for only about $2 \%$ of the minerals in coal slime, which is consistent with the semiquantitative analysis by XRD. The results indicate that the deportment of pyrite is mainly consistent with that of clay. Therefore, pyrite might be removed with the removal of clay.

\section{Float-and-sink experiment and correlation analysis}

As shown in Figure 4, arsenic removal decreased considerably as separation density increased from 1.4 to $2.0 \mathrm{~g} / \mathrm{cm}^{3}$, which can be ascribed to the mode of occurrence of arsenic. Although $96 \%$ of the total arsenic was removed at separation density $1.4 \mathrm{~g} / \mathrm{cm}^{3}$, the cumulative yields of clean coal and ash were only $5.7 \%$ and $5.0 \%$, respectively. It is therefore clear that gravity separation is not effective for the removal of arsenic. As shown in Figure 5(b), there is a negative correlation between the removal of arsenic and the content of ash $\left(R^{2}=0.98597\right)$, which indicates the inorganic affinity of arsenic. The removal of iron and aluminium have a positive correlation with that of arsenic (R2=0.9964 and 0.94565)

(Figure 5a), as would be expected given their dominant occurrence in pyrite and clay. Thus both pyrite and clay are the predominant carriers of arsenic in coal slime. Furthermore, the intercepts of the regression equations $(0.32888 \%$ and $5.24577 \%)$ indicate that a small amount of arsenic might occur in the form of other minerals.

Table /I

\section{The content of major minerals in coal slime}

\begin{tabular}{|l|c|c|c|c|}
\hline Mineral species & Clay & Pyrite & Quartz & Other \\
\hline Content (\% by volume) & 85 & 11 & 2.2 & 1.5 \\
\hline
\end{tabular}

\section{Selective leaching}

igure 6 shows the results of the consecutive selective leaching tests. In total, $91 \%$ of arsenic is leached by the four solvents,

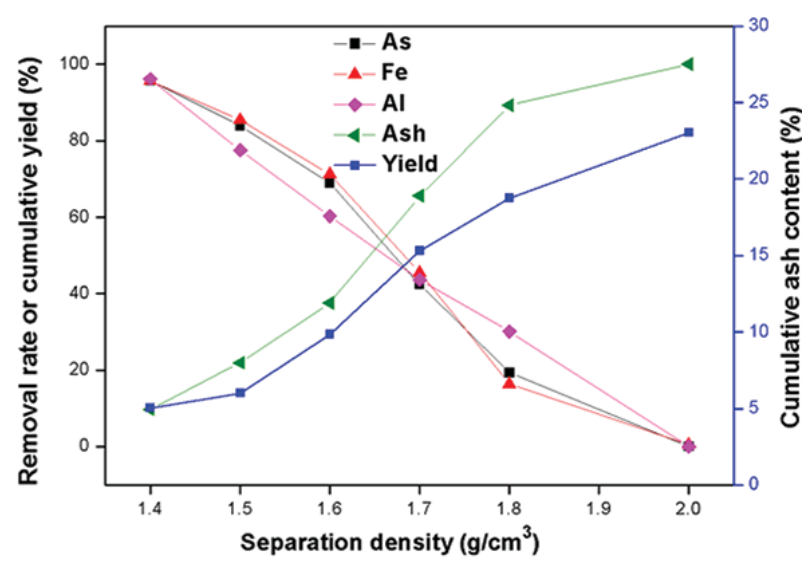

Figure 4-Float-and-sink tests on coal slime

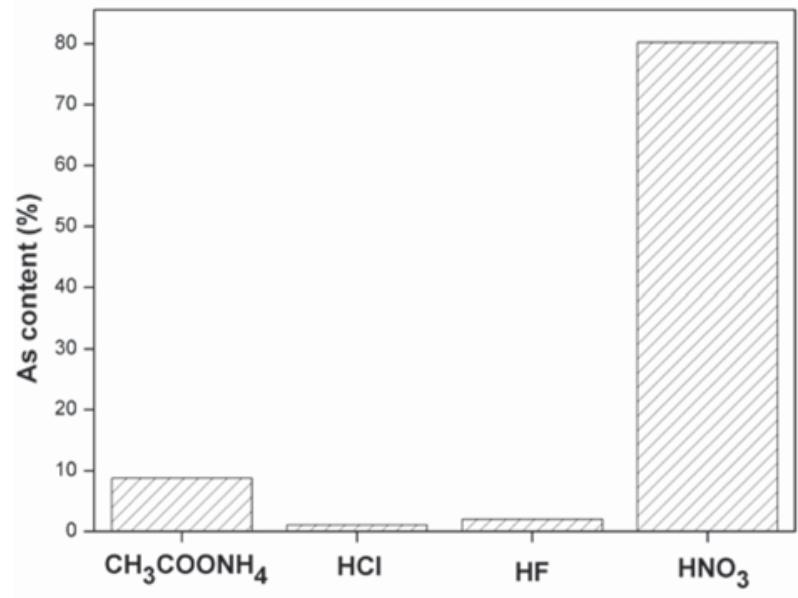

Figure 6-Arsenic removal from the coal slime under various selective leaching conditions

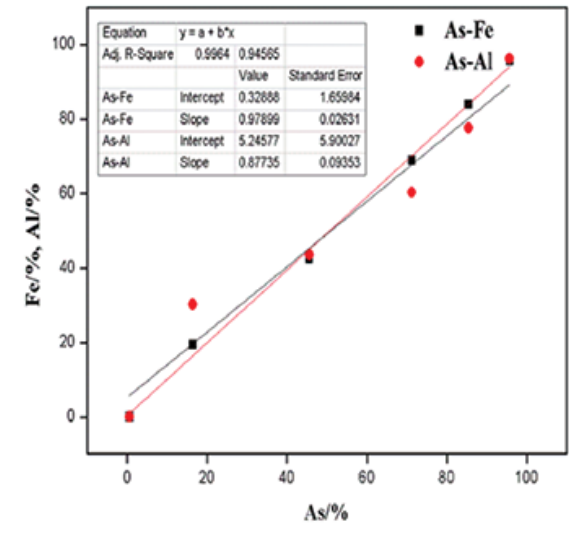

(a)

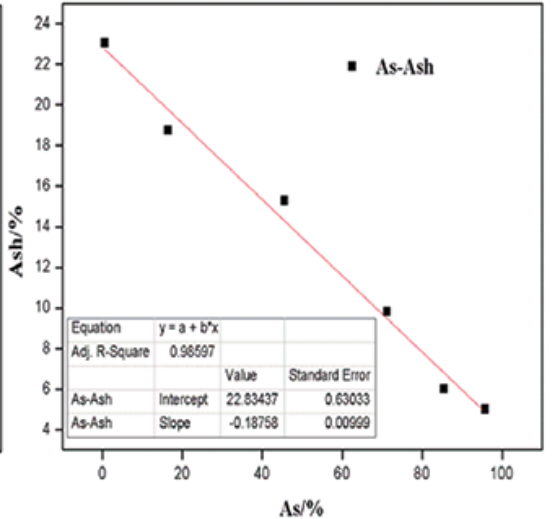

(b)

Figure 5-Correlation analysis based on the float-and-sink tests 


\section{Modes of arsenic occurrence in coal slime and its removal}

and the $\mathrm{HNO}_{3}$-leachable arsenic accounts for $77 \%$. This indicates the dominant association of arsenic with pyrite, which is consistent with previous reports (Finkelman, 1994; Huggins et al. 2009; Kang et al., 2011; Zheng, Liu, and Chou, 2008; Zhou et al., 2014). The results of selective leaching on the predominant carrier of arsenic are different from the correlation analysis, because the pyrite is predominantly embedded in clay (Figure 3). A small fraction of arsenic is removed by $\mathrm{HF}$ and $\mathrm{HCl}$, which indicates that arsenic is not significantly associated with carbonates and silicates, which are leached by $\mathrm{HCl}$ and $\mathrm{HF}$, respectively (Kolker et al., 2000). The same result was also indicated from the correlation analysis. Zhou et al. also reported the existence of arsenic in clay and carbonate mineral (Zhou $e t$ al., 2014). The $9.0 \%$ of the arsenic not removed by the leaching procedure may occur in the organic matrix or in insoluble phases such as zircon or titanium dioxide (Gao, Lu, and Wang, 2010; Kolker et al., 2000).

\section{Direct flotation}

Direct flotation was carried out at ambient temperature using deionized water $(\mathrm{pH}=5.7)$ and a pulp density of $80 \mathrm{~g} / \mathrm{L}$ to remove some of the ash and arsenic from the coal. After flotation, the concentrate was dried, then analysed. The results showed a reduction in ash and arsenic contents of 55 and $54 \%$ respectively. The clean coal yield is approximately $58 \%$. In direct flotation, the removal of arsenic is low, because the carrier minerals of arsenic are closely combined with the organic matter in the form of fine particles and report to the clean coal during flotation.

Thus, low-intensity leaching should be carried out prior to the flotation step, since the acid lixiviant can penetrate into the coal particles and attack the arsenic carried minerals.

\section{Effects of combined low-intensity leaching-flotation}

Figure 7 shows the effects of low intensity leaching-flotation on the quality of clean coal. The pH of 5.7 corresponds to the result of direct flotation. After low-intensity leaching, the

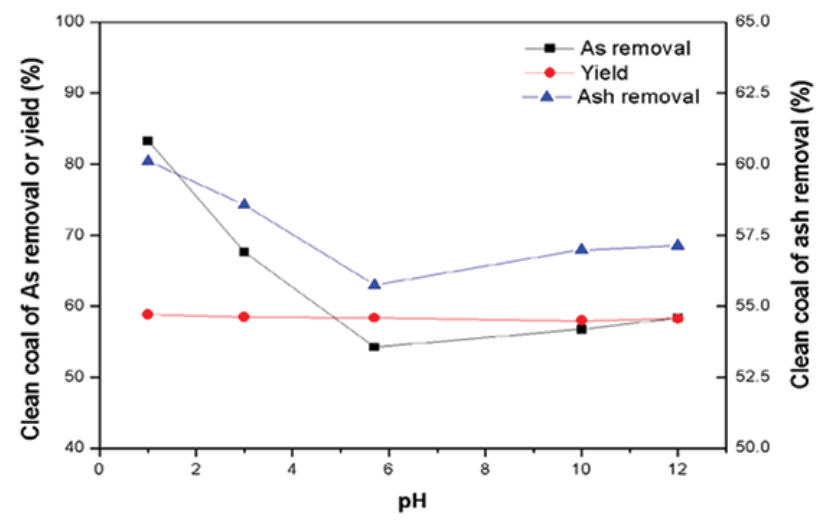

Figure 7-Effects of low-intensity leaching-flotation on the quality of clean coal.I (note: pH 5.7 corresponds to the results of direct flotation) yield of flotation concentrate is almost unchanged, approximately $58 \%$. When the $\mathrm{pH}$ of leaching is 12.0 , the removal of arsenic and ash after flotation is approximately $58 \%$ and $57 \%$, respectively. The removal of arsenic and ash by flotation increased considerably under acidic conditions of leaching and reached $83 \%$ and $60 \%$ at $\mathrm{pH}=1.0$, respectively. Direct flotation ( $\mathrm{pH}=5.7$ ) was found to be ineffective while low-intensity leaching-flotation is suitable, which could be ascribed to the dissolution of some minerals and the separation of minerals from the organic matter after leaching. The maximum removal of arsenic in low-intensity leachingflotation is lower than that in heavy medium separation (Figure 4), but the yield of clean coal is higher. Therefore, low-intensity leaching-flotation has some advantages compared with heavy medium separation and direct flotation.

Demir $e t$ al. reported that when the degree of removal of an element is greater than that of ash in the washing process, this element is more related with epigenetic minerals, and these minerals will be easily removed in the physical coal washing process (Demir et al., 1998). Arsenic is removed to a greater degree than ash (Figure 7), which indicates that the arsenic occurs mainly in epigenetic minerals.

\section{Effects of low-intensity leaching-flotation on removal of arsenic with different modes of occurrence}

The leaching-flotation behavior of arsenic with different modes of occurance was studied by selective leaching experiments. The results are shown in Figure 8. The considerable differences in behaviour can be ascribed to the dissolution of carrier minerals and the separation of minerals from the organic matter after leaching.

The removal of $\mathrm{CH}_{3} \mathrm{COONH}_{4}$-leachable arsenic by leaching-flotation is higher than that of $\mathrm{CH}_{3} \mathrm{COONH}_{4}^{-}$ leachable arsenic by direct flotation ( $\mathrm{pH}=5.7)$. The maximun removal of $\mathrm{CH}_{3} \mathrm{COONH}_{4}$-leachable arsenic is about $97 \%$ at $\mathrm{pH}$ 1.0. With alkali leaching-flotation, the removal of arsenic is

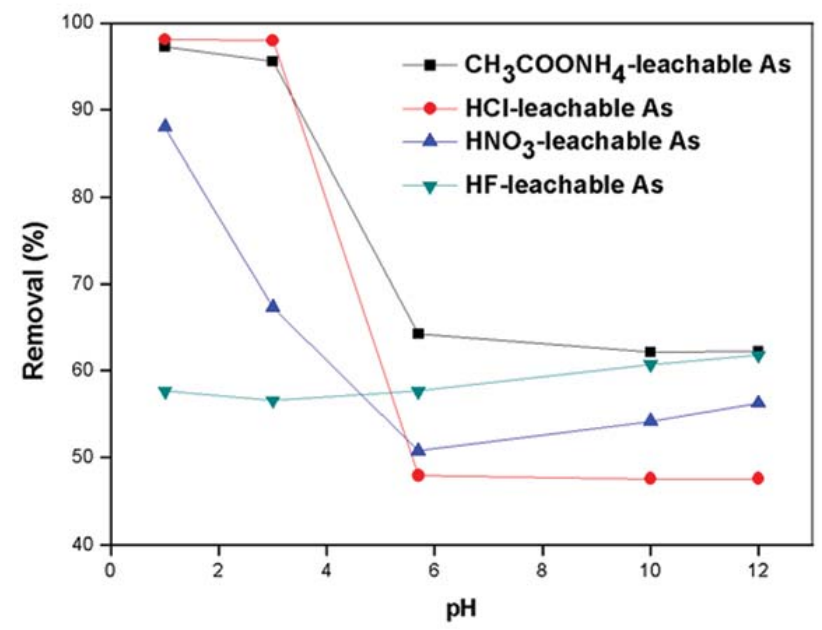

Figure 8-Effect of low-intensity leaching on remova of arsenicl with different modes of occurrences 


\section{Modes of arsenic occurrence in coal slime and its removal}

approximately $62 \%$ at $\mathrm{pH} 10.0-12.0$. This arsenic fraction generally exists in the pore water and carbonate or is adsorbed on the surface of organic matter and minerals (Gao, $\mathrm{Lu}$, and Wang, 2010). After acid leaching-flotation, nitric acid reacts with calcite inducing the release of arsenic ions, and arsenic ions desorb from the surface of organic matter and minerals due to competitive adsorption and dissolution in the leaching medium and are removed by flotation. In alkaline leaching-flotation, alkaline conditions restrain desorption and exchange of arsenic ions in comparison to direct flotation $(\mathrm{pH}=5.7)$, which in turn decreases the removal of $\mathrm{CH}_{3} \mathrm{COONH}_{4}$-leachable arsenic.

The degree of removal of $\mathrm{HCl}-$ leachable arsenic increased considerably as $\mathrm{pH}$ decreased from 5.7 to 1.0 and the maximum removal of arsenic is $98 \%$ at $\mathrm{pH} 1.0$. Under alkaline conditions, the removal of $\mathrm{HCl}-$ leachable arsenic fluctuated around $47 \%$. HCl-leachable arsenic is primarily associated with carbonates and monosulphides such as sphalerite, galena, and chalcopyrite, which are dissolved by $\mathrm{HCl}$. The acid reacts with carbonates and monosulphides, inducing the release of arsenic ions and carrier minerals of arsenic. The floatability of carrier minerals (carbonates and monosulphides) is weaker than that of coal. Therefore, the likeliness of $\mathrm{HCl}$-leachable arsenic reporting to clean coal is reduced. However, carbonates and monosulphides do not react with alkalis so the removal of $\mathrm{HCl}$-leachable arsenic is similar to that by direct flotation.

The removal of $\mathrm{HNO}_{3}$-leachable arsenic is close to that of total arsenic, because the dominant arsenic fraction is removed by $\mathrm{HNO}_{3}$ as shown in Figure 5. Disulphides, such as pyrite and marcasite, are dissolved by $\mathrm{HNO}_{3}$ (Equation [1]). The removal of $\mathrm{HNO}_{3}$-leachable arsenic showed a significant increase as the $\mathrm{pH}$ decreased from 5.7 to 1.0 and reached $88 \%$ at $\mathrm{pH} 1.0$. There was a slight increase in arsenic removal under alkaline leaching, reaching $56 \%$ at pH 12.0. Chemical leaching is an effective method for coal desulphurization and de-ashing. Pyritic sulphur is usually extracted by direct method with acid (Xia, Xie, and Peng, 2015). In the present study, the reaction between pyrite and acid in low intensity leaching process can be described by Equation [2].

$$
\begin{aligned}
& 2 \mathrm{FeS}_{2}+30 \mathrm{HNO}_{3} \text { (Concentrated) } \rightarrow \\
& \mathrm{Fe}_{2}\left(\mathrm{SO}_{4}\right)_{3}+30 \mathrm{NO}_{2} \uparrow+14 \mathrm{H}_{2} \mathrm{O}+\mathrm{H}_{2} \mathrm{SO}_{4} \\
& \mathrm{FeS}_{2}+4 \mathrm{HNO}_{3} \text { (Dilute) }+1 / 2 \mathrm{O}_{2} \rightarrow \\
& \mathrm{Fe}\left(\mathrm{NO}_{3}\right)_{3}+2 \mathrm{~S} \downarrow+\mathrm{NO}_{2}+2 \mathrm{H}_{2} \mathrm{O}
\end{aligned}
$$

Compared to the other lixiviants, the removal of HFleachable arsenic is erratic as the amount of arsenic associated with silicates is highly variable. Gao, Ju, and Wang (2010) reported that some minerals are completely encased by organics or a silicate matrix, hence digestion of the sample may not be complete.

\section{The influence of low-intensity leaching on flotation}

Pre-leaching changed the response of the gangue minerals to flotation, which in turn affected the arsenic removal process. $\mathrm{HNO}_{3}$ and $\mathrm{NaOH}$ were added to the deionized water to adjust the $\mathrm{pH}$ to $1.0,3.0,5.7,10.0$ and 12.0 in order to compare the flotation behaviour of gangue in an acid, neutral, and alkaline environment. The testing process was the same as for slime leaching-flotation. The results are shown in Figure 9. Gangue yield decreased with increasing acidity or basicity compared to neutral conditions. Thus, flotation under acid or basic condition promotes arsenic removal from clean coal.

\section{The effect of low-intensity leaching on alkaline environment flotation}

Fine mud coating is ascribed to the change of zeta potential on the mineral surface (Gaudin, Fuerstenau, and Miaw, 1960; $\mathrm{Xu}$ et al., 2003), and is detrimental to de-ashing and arsenic removal. The zeta potential of fine mud, coal particles and coal slime showed a reduction with increasing $\mathrm{pH}$ (Figure 10). The zeta potential of coal slime gradually approached that of coal particles with increasing $\mathrm{pH}$ to 9.0, and then gradually approaches that of fine mud as $\mathrm{pH}>9.0$. This phenomenon indicates that fine mud covers the surface of

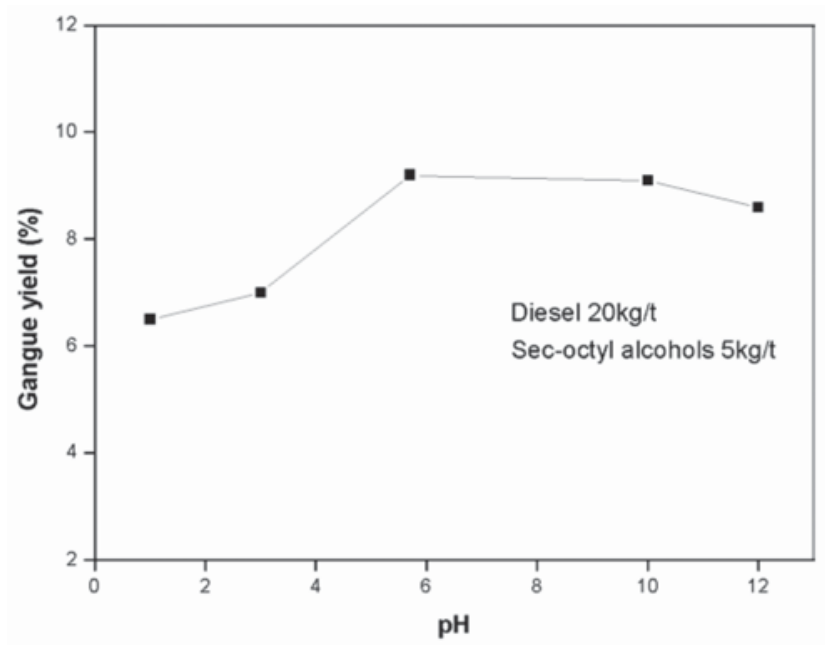

Figure 9-The impact of $\mathrm{pH}$ value on the flotability of gangue

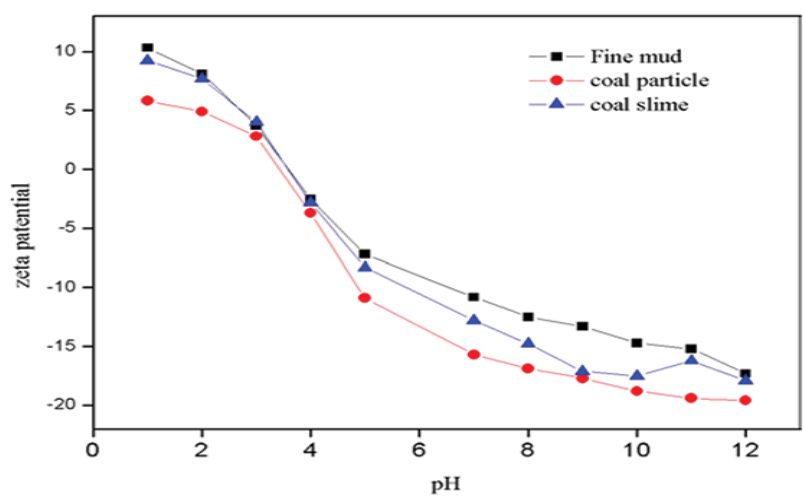

Figure 10- Impact of pH on zeta potential of fine mud, coal particles and coal slime 


\section{Modes of arsenic occurrence in coal slime and its removal}

\begin{tabular}{|l|c|c|}
\hline \multicolumn{3}{|l|}{$\begin{array}{l}\text { Table } \\
\text { Process comparison analysis }\end{array}$} \\
\hline Process & Arsenic reduction, \% & Ash, \% \\
\hline Leaching-flotation $(\mathrm{pH}=1)$ & 83 & 59 \\
Flotation- alkali washing - leaching & 86 & 61 \\
\hline
\end{tabular}

coal as $\mathrm{pH}<7.0$ and $\mathrm{pH}>10.0$. Therefore, a weak alkaline environment is beneficial for the dispersion of fine mud.

The removal of arsenic and ash by flotation increased considerably to $86 \%$ and $61 \%$, respectively, $3 \%$ and $2 \%$ higher than that of low-intensity leaching-flotation alone. The results show that low-intensity leaching-alkali washingflotation is beneficial for the removal of arsenic in coal compared with direct flotation and low-intensity leachingflotation. In addition, an alkaline environment increases the hydrophobicity of the surface of pyrite (Moslemi, Shamsi, and Habashi, 2011) and contributes to enhancing the mobility of arsenic oxyanionic species which usually adsorbed on the surface of organic matter and minerals (Cornelis et al., 2008).

\section{Conclusions}

Most of the arsenic in Tanggongta coal slime is associated with pyrite. The presence of pyrite-hosted arsenic is proven by selective leaching because the dominant arsenic fraction was removed by leaching with $\mathrm{HNO}_{3}$. Examination by polarizing microscope showed that pyrite is mostly embedded in kaolinite as fine grains.

Low-intensity leaching-flotation is more efficient for arsenic removal compared with heavy medium separation and direct flotation. The removal of arsenic and ash after low-intensity-flotation increased considerably and reached $83 \%$ and $60 \%$ at $\mathrm{pH}=1$, respectively.

Under acid leaching, the $\mathrm{CH}_{3} \mathrm{COONH}_{4}$-leachable arsenic and $\mathrm{HCl}$-leachable arsenic are the easiest removable fractions to remove, and $\mathrm{HF}$-leachable arsenic the most difficult. The recoveries of $\mathrm{CH}_{3} \mathrm{COONH}_{4}$-leachable arsenic and $\mathrm{HCl}$ leachable arsenic were over $97 \%$, and that of HF-leachable arsenic and $\mathrm{HNO}_{3}$-leachable arsenic $88 \%$ and $57 \%$, respectively. Under alkaline leaching, the decreasing sequence of highest recovery is $\mathrm{CH}_{3} \mathrm{COONH}_{4}, \mathrm{HF}, \mathrm{HNO}_{3}$ and $\mathrm{HCl}$ leachable fractions. The leaching had different influences on arsenic removal, depending on the reactivity towards acids and bases, the amphiphilic properties of the reaction products, and mode of occurance of the carrier minerals.

The floatability of gangue was reduced with an increase in acidity or basicitycompared to neutral conditions. Therefore, ash removal was improved, which in turn decreased the content of arsenic in clean coal.

A weakly alkaline environment is of advantage for the dispersion of the pulp. The removal of arsenic in the low- intensity leaching-alkaline washing-flotation process is 3\% higher than that of low-intensity leaching-flotation alone, which can be ascribed to the dispersion of pulp.

\section{Acknowledgments}

This work was supported by the National Key Basic Research Program of China (Grant Nos. 2014CB238905) and the Priority Academic Program Development of Jiangsu Higher Education Institutions.

\section{Reference}

Cornelis, G., Poppe, S., Van Gerven, T., Van Den Broeck, E., Ceulemans, M., and VANDECASTEELE, C. 2008. Geochemical modelling of arsenic and selenium leaching in alkaline water treatment sludge from the production of nonferrous metals. Journal of Hazardous Materials, vol. 159. pp. 271-279.

Demir, I., Ruch, R.R., Damberger, H.H., Harvey, R.D., Steele, J.D., and Ho, K.K. 1998. Environmentally critical elements in channel and cleaned samples of Illinois coals. Fuel, vol. 77. pp. 95-107.

DieHL, S.F., Goldhaber, M.B., and HATch, J.R. 2004. Modes of occurrence of mercury and other trace elements in coals from the warrior field, Black Warrior Basin, Northwestern Alabama. International Journal of Coal Geology, vol. 59. pp. 193-208.

Dai, S., Seredin, V.V., Ward, C.R., JiAng, J., Hower, J.C., Song, X., Jinag, Y., WAnG, X., Gornostaeva, and T., Li, X. 2014. Others Composition and modes of occurrence of minerals and elements in coal combustion products derived from high-Ge coals. International Journal of Coal Geology, vol. 121. pp. 79-97.

FinkeLman, R.B. 1994. Modes of occurrence of potentially hazardous elements in coal: levels of confidence. Fuel Processing Technology, vol. 39. pp. 21-34.

Finkelman, R.B., Belkin, H.E., and Zheng, B. 1999. Health impacts of domestic coal use in China. Proceedings of the National Academy of Sciences USA, vol. 96. pp. 3427-3431.

Finkelman, R.B., Orem, W., Castranova, V., Tatu, C.A., Belkin, H.E., Zheng, B., Lerch, H.E., Maharaj, S.V., and BATES, A.L. 2002. Health impacts of coal and coal use: possible solutions. International Journal of Coal Geology, vol. 50. pp. $425-443$.

Fujino, Y., Guo, X., Liu, J., You, L., Miyatake, M., Yoshiura, T., and Group, J.I.M.A. 2004. Others Mental health burden amongst inhabitants of an arsenic-affected area in Inner Mongolia, China. Social Science and Medicine, vol. 59. pp. 1969-1973.

FENG, L.P. 2009. The study of mercury Occurence in coal and Migration Regularity during coal preparation. China University of Mining and Technology, Bijing. 


\section{Modes of arsenic occurrence in coal slime and its removal}

Fan, X., Jiang, J., Chen, L., Zhou, C.C., Zhu, J.L., Zhu, T.G., and Wei, X.Y. 2016. Identification of organic fluorides and distribution of organic species in an anthracite with high content of fluorine. Fuel Processing Technology, vol. 142. pp. $54-58$

Gaudin, A.M., Fuerstenau, D.W., and Miaw, H.L. 1960.Slime coatings in galena flotation. CIM Bulletin, vol. 53. pp. 960-963.

GAo, J.S., Lu, J., and WANG, J. 2010. Coal chemical process of pollution and control, Chemical Industry Press:

HALL, A.H. 2002. Chronic arsenic poisoning. Toxicology Letters, vol. 128. pp. 69-72.

Hugginss, F.E., Seidu, L., Shah, N., Huffman, G.P., Honaker, R.Q., Kyger, J.R., Higgins, B.L., Robertson, J.D., PAL, S., and SeEhra, M.S. 2009. Elemental modes of occurrence in an Illinois \#6 coal and fractions prepared by physical separation techniques at a coal preparation plant. International Journal of Coal Geology, vol. 78. pp. 65-76.

JIANG, Y., Fu, C., BAI, X., and LI, W. Distribution features of arsenic content in China coal. Coal Scicience and Technology, vol. 2. p. 30.

Kolker, A., Goldhaber, M.B., Hatch, J.R., Meeker, G.P., and Koeppen, R.P. 1999. Arsenic-rich pyrite in coals of the warrior field, northwestern Alabama: Mineralogical evidence for a hydrothermal origin. Geological Society of America, Abstracts with Programs.

Kolker, A., Huggins, F.E., Palmer, C.A., Shah, N., Crowley, S.S., Huffman, G.P., and Finkelman, R.B. 2000. Mode of occurrence of arsenic in four US coals. Fuel Processing Technology, vol. 63. pp. 167-178.

Kang, Y., Liu, G., Chou, C., Wong, M.H., Zheng, L., and Ding, R. 2011.Arsenic in Chinese coals: Distribution, modes of occurrence, and environmental effects. Science of the Total Environment, vol. 412. pp. 1-13.

LutTRELl, G.H., KoHmUENCH, J.N., and Yoon, R. 2000. An evaluation of coal preparation technologies for controlling trace element emissions. Fuel Processing Technology, vol. 65. pp. 407-422.

Meshram, P., Purohit, B.K.., Sinha, M.K.., Sahu, S.K., and Pandey, B.D. 2015. Demineralization of low grade coal - a review. Renewable and Sustainable Energy Review, vol. 41. pp. 745-761.

Moslemi, H., Shamsi, P., and Habashi, F. 2011. Pyrite and pyrrhotite open circuit potentials study: effect on flotation. Minerals Engineering, vol. 24. pp. 1038-1045.

PIETRZAK, R. and WACHOWSKA, H. 2006.The influence of oxidation with hno3 on the surface composition of high-sulphur coals: xps study. Fuel Processing Technology, vol. 87. pp. 1021-1029.
Quich, W.J. and Irons, R. 2002. Trace element partitioning during the firing of washed and untreated power station coals. Fuel, vol. 81,.pp. 665-672.

Qiao, J., JiAng, Z., Sun, B., Sun, Y., Wang, Q., and Guan, X. 2012. Arsenate and arsenite removal by $\mathrm{FeCl}_{3}$ : effects of $\mathrm{pH}$, As /Fe ratio, initial as concentration and co-existing solutes. Separation of Purification Technology, vol. 92. pp. 106-114.

Smith, A.H.., Hopenhayn-Rich, C., Bates, M.N., Gorden, H.M., HerTZ-Picciotto, I., Duggan, H.M., Wood, R., KosnetT, M.J., and Smith, M.T. 1992. Cancer risks from arsenic in drinking water. Environmental Health Perspectives, vol. 97. p. 259.

Smedley, P.L., Zhang, M., Zhang, G., and Luo, Z. 2003. Mobilisation of arsenic and other trace elements in fluviolacustrine aquifers of the huhhot basin, inner Mongolia. Applied Geochemistry, vol. 18. pp. 1453-1477.

WAUGH, A.B. and Bowling, K.M. 1984.Removal of mineral matter from bituminous coals by aqueous chemical leaching. Fuel Processing Technology, vol. 9. pp. 217-233.

WARREN, L.J. 1985.Determination of the contributions of true flotation and entrainment in batch flotation tests. International Journal of Minerral Processing, vol. 14. pp. 33-44.

Wang, W.F.,, QIN, Y., Wei, C., Li, Z., Guo, Y., and ZHu, Y. 2006. Partitioning of elements and macerals during preparation of antaibao coal. International Journal of Coal Geology, vol. 68. pp. 223-232.

Xu, Z., Liv, J., Choung, J.W., and Zноu, Z. 2003. Electrokinetic study of clay interactions with coal in flotation. International Journal of Mineral Processing, vol. 68. pp. 183-196.

XIA, X., XIE, G., and Peng, Y. 2015. Recent advances in beneficiation for low rank coals. Powder Technology, vol. 277. pp. 206-221.

Zheng, B.S., Ding, Z.H., Huang, R.G., Zhu, J.M., Yu, X Y., Wang, A.M., Zhou, D. X., MAO, D.J., and Su, H.C. 1999. Issues of health and disease relating to coal use in southwestern china. International Journal of Coal Geology, vol. 40. 119-132.

Zheng, L., Liu, G., and Chou, C. 2008.abundance and modes of occurrence of mercury in some low-sulfur coals from china. International Journal of Coal Geology, vol. 73. pp. 19-26.

Zhou, C.C., Liu, G.J., Wu, D., Fang, T., Wang, R.W., and Fan, X. 2014. Mobility behavior and environmental implications of trace elements associated with coal gangue: a case study at the Huainan coalfield in china. Chemosphere, vol. 95, pp. 193-199. 